\title{
Application of economic instruments, tradable licenses and good governance for sustainable water conservation
}

\author{
W. L. Nieuwoudt ${ }^{1} \&$ G. R. Backeberg ${ }^{2}$ \\ ${ }^{1}$ University of KwaZulu Natal, South Africa \\ ${ }^{2}$ Water Research Commission, South Africa
}

\begin{abstract}
According to the National Water Policy in South Africa the objectives are to achieve equitable access to water, and to promote efficient and sustainable use for optimum social and economic benefit. The National Water Act provides the legal framework and the National Water Resource Strategy explains the ways in which water resources will be managed. Several inter-related actions are taken to implement water conservation and demand management. The results of completed and ongoing research projects in South Africa demonstrate the application of technologies for direct and indirect water measurement in rivers, canals and pipelines. Decision support systems are available to determine the cost of irrigation and assess the risks of agricultural water management on farms. Empirical analyses have been done of temporary or permanent transfers and lease or trade of water use entitlements on irrigation schemes with stable and variable water supply. The establishment and functioning of catchment management agencies (CMA's) for local water management by different water use sectors including irrigation have been evaluated. Based on these studies it is concluded that volumetric charging and cost recovery of water supply services through a two-part charging system is practically feasible. Complete description of water use entitlements and provision of information must improve to increase security and reduce the risks associated with market trades. Training and capacity building is essential to support participation by all water users and maintain standards of accountability for irrigation management.
\end{abstract}

Keywords: water user charges, water marketing, water governance. 


\section{Introduction}

Several studies have been undertaken to assist with the implementation of the new National Water Act (NWA) of 1998 and the National Water Resource Strategy (NWRS) of 2004 [1] by the Department of Water Affairs and Forestry (DWAF). The NWA brought about a new framework for water resource management in South Africa. Water resources should accordingly be allocated in a way that will ensure its "best possible use". The "best possible use" entails more than the productive use of water since in addition social, economic and environmental factors must be included to achieve the objectives of equity, efficiency and sustainability of water use. These issues will be analysed and discussed in the paper. The paper is mainly based on completed and ongoing research projects managed and funded by the Water Research Commission.

\section{Some theoretical and practical considerations}

Water markets are based on a system of water law that displays three attributes: security, stability, and flexibility in protecting transferability of property rights. Security is the ability to identify and gain protection for the right of use. Stability assumes that the right of use will continue to be recognised. Flexibility allows the right of use to be transferred to another use. The flexibility of being able to transfer a water right adds value to it because the market value of the right reflects not only the value of current use but also that of future opportunities. Security and stability in water markets are important, as it will affect investment.

An economic explanation of "best use" will be given as it was attempted to study this empirically in projects reported in this paper. The economic interpretation of efficient use of water is that the return per cubic meter of water must be maximized. The full economic cost of water consists of financial, opportunity and external costs. In a water market the rent return to water is maximized as water moves to a better use. In the rent return to water, risk is reflected as a cost (opportunity cost). The economic meaning of efficiency of water use and the rent return to water are thus synonymous concepts. Supply risk is often high where not sufficient storage dams exist. This is important in South Africa as in the irrigation areas of the Crocodile River, water use rights moved from a high risk environment to an environment where lower risk crops such as sugar-cane can be produced.

It is also often stated that water markets are not effective because of few trades. This statement may miss probably the biggest contribution of a water market: It discovers the opportunity cost of water and all water users, including the non buyers/sellers, are faced by this opportunity cost and are provided incentives to conserve water resources. However, participation in the water market is only possible by water users who have existing rights and have access to funds. Due to the history of South Africa, unequal allocation of use rights was caused by racially discriminatory legislation. This unequal distribution cannot be corrected by the market process alone. Political and legal negotiations are necessary to achieve equity through water allocation reform (Backeberg [2]). 


\section{Economic instruments for water conservation}

\subsection{Charges for water resource development and use}

A user charge is a non-market economic instrument, similar in nature to regulation or administrative control of a resource and is used to encourage the conservation of water resources. The charge is levied by Government or a Catchment Management Agency (CMA) or a Water User Association (WUA) to recover the costs for providing a service to supply the allocated water. There is an exchange relationship between e.g. Government as 'supplier' of the service and the user as the 'buyer'. In the case of a quasi-collective service such as the supply of irrigation water, the farming public pays a 'price' for such a service known as a user charge (Gildenhuys [3]). Such instruments may ration or change resource use in the intended direction but is classified as ineffective if the market for allocation of water resources is not functioning.

The NWA provides for three types of water user charges to achieve water conservation and demand management (DWAF [1]): (a) water resource management charges to fund the controlling, monitoring and protection of water resources in a catchment; (b) water resource development charges which recover the cost of planning, designing, constructing, operating and maintaining water supply schemes; and (c) charges for achieving equitable and efficient water allocation which relate to the value of water. The latter charge has not been applied administratively (Genesis Analytics [4]). The purpose of the first two financial charges is cost recovery while the objective of the third economic charge is purportedly to provide incentives to shift water from lower to higher value uses. The imposition of user charges such as under (a) and (b) is justified since the subsidisation of irrigation schemes in the long run creates distortions by not relating actual costs to water supply. Charges to cover costs therefore make business and economic sense.

For commercial farmers the subsidy on operation and maintenance (O\&M) costs has therefore been phased out. In contrast, for emerging and subsistence farmers the O\&M charges for water supply will be subsidised at a reducing scale over five years. Currently user charges are levied on an area basis but with measurement of water use, volumetric charges will be instituted. The theoretical soundness of proposing a charge as envisaged under (c) in order to achieve equitable and efficient water allocation is questionable. Such a charge is in fact a tax which reduces the expected returns for productive use of water and is therefore rather a disincentive to transfer water. It is a fallacy to argue that economic charges will promote further conservation of water as resources are allocated based on opportunity cost and not financial cost. In fact the user charges do not change the opportunity cost faced by the irrigator as the sum of the tax and the water rent (which is lower because of tax) will stay unchanged. Where the characteristics of a resource is conducive to the formation of a market, such as in the case of explicit, exclusive, enforceable and transferable water use entitlements, the most effective and efficient mechanism to promote resource conservation is to promote markets. 


\subsection{Costing of water use}

In addition to user charges for water services, provision has to be made for onfarm cost of water abstraction, storage, distribution and application. These irrigation cost form a significant (15-27\%) of the variable cost of commercial crop production. Before an investment decision is made, the capital and operating cost of irrigation equipment must therefore be evaluated. The program IrriCost has been developed to estimate the annual capital and operating cost of irrigation (Meiring et al. [5]). This tool can be used to do cost comparisons of alternative designs, analyse annual cost of water use and compile budgets of irrigation costs. Apart from escalating costs, farmers are confronted with changing yields and prices. The model RiskMan was developed to provide information for risk management in irrigation farming. With the aid of this model, information can be processed to be useful for decision-making at enterprise and whole-farming level. These costing procedures taking risk into account have been applied and tested for small- and large-scale commercial farmers in the Nkomazi region of the Komati and Crocodile Rivers (Oosthuizen et al. [6, 7]). For small-scale farmers a subsidy on capital is crucial for financial survival while for large-scale farmers the simultaneous replacement of orchards and irrigation equipment has a severe effect on financial feasibility and riskiness of farming. The full financial cost of irrigation, i.e. capital, operating and maintenance cost were similarly evaluated in a separate case study of smallholder subsistence farming (Perret and Geyser [8]). The results show high cost of irrigation services in comparison with income from irrigation. This finding supports the approach adopted by DWAF to gradually increase charges for water development and use by subsistence farmers.

\section{Hydrological issues}

\subsection{Metering and complete description of water use entitlements}

The security of water use rights implies that it can be monitored and enforced which further implies that it can be measured. A process is underway to measure or meter water in South Africa. In this regard it has been shown that technologies are available for direct and indirect measurement of water conveyance in rivers, canals and pipelines. The challenge in practice is managed implementation of the water measuring system, both by individual farmers and by WUA's (Van der Stoep et al. [9]). Various conditions for licensing of water use, including installation of water measuring devices, are furthermore being implemented by DWAF [10]. As a whole these actions to measure and monitor should contribute to a clearer specification and enforcement of water use entitlements. Illegal use of water is an impediment to a water market especially in two water stressed areas namely the Olifants River (East) and Crocodile River (East) recently visited as part of a Water Research Commission project (2006/7). In the Olifants River water is metered and monitored in the Loskop and Blyde River irrigation areas and there is no room for illegal use. 


\subsection{Water quality impacts}

Not only the volume of water must be conserved but its quality must be protected. With pollution of water, external costs are generated. The Berg River in the Cape was recently (2007) visited. Stakeholders concerned with the quality have formed an action group in this river. Water quality is also a concern in the Olifants River (East), one of the main rivers in South Africa. Coal mines on this river are allegedly blamed for discharges in the river. The policy recommendations to improve the water quality in this river were highlighted after meeting stakeholders of the Olifants Forum during 2006. Strong support from these stakeholders was received for policy options such as pollution permit trading and environmental offsets. The catchment surface of the Olifants River is fractured by mining activities, runoff decreases and water is drained into underground aquifers which then seeps into streams. A waste discharge charge system is proposed by DWAF [11] but at present, discharges in the catchment are not levied. It is recommended that polluters should pay a discharge rate, in the same way as water abstraction users pay water charges.

As in the case of a water market it is proposed that a market be established for the discharge of pollutants and that this market is used to discover the optimum price for pollutant disposal. This proposal is supported by representatives of some mines (Lodewijks [12]). All markets operate within certain rules. In a pollution permit trading market, rules that may be considered are that discharges in the river are only allowed when flow is sufficiently high and that trades may only occur within certain parameters. A permit trading program could complement desalination plants as some costs of these plants may be variable (reservoirs where the pollutants solidify fill up). Apart from a pollution trading program it is suggested that bio-diversity offsets be created to provide incentives for cooperation amongst stakeholders which may be mines, developers, environmental groups, farmers and public land agencies. Expert opinion is that the main source of pollution in the Loskop Dam is the leakage from abandoned old mines (pre-1956). The problem with the defunct mines is that they leak pollutants all the time including during the period when river flow is low. DWAF has apparently accepted responsibility for these mines but they may not have the appropriate technology, which is also expensive, to desalinate the effluent. In an offsetting arrangement, incentives can be provided to existing mines to desalinate water from these defunct mines by allowing them to discharge a given amount in the Olifants when the water flow is sufficiently high. The above arrangement will cost the taxpayer nothing while discharge during low flow periods is reduced.

\section{Empirical results of water marketing studies}

\subsection{Efficiency of water use}

Studies undertaken in several rivers in South Africa showed that water market trading promotes the more efficient use of water (Gillitt [13], Armitage [14]). 
Water market trading will promote some of the objectives as stated in the Water Allocation Reform document [15] by supporting growth and development and by maximising the return, adjusted for risk per unit of water.

A discriminant analysis of water market transfers in the Lower Orange River showed that water user rights were transferred to farmers with the highest return per unit of water applied, those producing table grapes, and with a high potential arable 'outer land' without water entitlements (Armitage [14]). In this analysis the return per unit of water applied was the most significant of the variables studied and also had the highest standardised regression coefficient. It is concluded that the market promoted the more efficient use of water. Buyers of water entitlements only modestly used more water conservation technology as both buyers and sellers face almost the same opportunity cost. The opportunity costs faced by buyers are slightly more because of transaction cost. Only unused water was transferred, while water saved (through adoption of conservation practices) was retained possibly for security purposes.

A second study by Armitage [14] in the Nkwaleni Valley in northern KwaZulu-Natal found that no water market had emerged despite the scarcity of water in the area. No willing sellers of water rights existed. Transaction costs appear larger than benefits from trading. Farmers generally retain surplus rights as security against drought because of unreliable river flow while crop profitability in this area is similar for buyers and sellers (they grow the same crops). If potential buyers are compared with potential sellers then the most important variable that discriminated between them was that buyers produced sugar-cane. The reason being that sugar-cane can better withstand drought than competing crops. This may be attributed to the irregular river flow, a finding that was also observed in the Crocodile River (Gillitt [13]).

A follow-up study by Gillitt [13] was undertaken among irrigation farmers in the Boegoeberg and Kakamas Irrigation Schemes along the Orange River of South Africa who had transferred water entitlements between January 1998 and August 2003. A total of 37 farmers were interviewed. A Principal Component Analysis of factors associated with buyers in the Orange River was conducted. This indicated that buyers of water entitlements have a higher income per cubic meter of water applied, a larger percentage of cropped area planted to lucrative export table grapes and horticultural crops, larger advanced irrigation technology while it has a negative loadings with the percentage of cropland planted to other grapes and percentage of planted to field crops (lower return). This indicates that a water market promotes efficiency in water use and that water is transferred to high income crops (table grapes and horticultural crops). These relationships were confirmed in regression models (Ridge Regression, Logit Regression).

\subsection{Risk in water marketing}

Policy risk and risk aversion appear to be important in explaining future investment in irrigation farming in the Lower Orange River. These farmers are also highly risk averse especially regarding downside risk. Important policy implications are that farmers should be better informed about the practical implications of the National Water Act and specifically water licenses. The 
characteristics of buyers and sellers of water differ in the Crocodile and Orange rivers. In the Orange River where water supply appears more stable (due to large irrigation dams) water is transferred from farmers where the return per cubic meter of water is low to farmers where the return is high. In the Lower Crocodile River where water supply is highly irregular, water is transferred from farmers where risk is high to farmers where lower risk crops such as sugar-cane can be produced.

The risk aversion of irrigation farmers was measured by the Arrow/Pratt Absolute Risk Aversion Coefficient (APAR) (standardised for scale and range of data) (Nieuwoudt et al. [16]). The empirical investment model shows that farmers who are more risk averse, expect to invest less in the future. Farmers are more risk averse (down-side risk) than anticipated in the questionnaire as almost all the farmers picked the most risk averse category.

\section{Equity with water allocation}

One of the main objectives of the National Water Policy in South Africa is to achieve equitable access to water. A target has been set that at least $30 \%$ of water must move towards Previous Disadvantaged Individuals (PDI's) due to racially discriminatory legislation. If irrigation water is provided to PDI's then they will still have to be provided with suitable irrigable land which is a problem as most of the suitable land is already under cultivation. It does not make sense if water is moved from a developed farm which has little production potential without water and channelling it to a new farm that must still be developed. The development cost of irrigation farming is high and providing them with water only does not make sense. It is proposed that the most effective way to redistribute water to PDI's is through the Government programs of restitution and redistribution of land. The value of water is capitalized in the value of a farm and empowering a PDI to own a farm also provides him access to the water rights of the farm. PDI's not only need water and land but other support services to build their capacity which includes training. This implies coordination of actions from the government departments of Land Affairs, Water Affairs and Forestry, Agriculture (extension service) while other stakeholders need to be included such as the Land Bank of South Africa (financing) and commercial farmers.

\section{Governance in water management}

Water governance refers to the range of political, social, economic and administrative systems that are in place to develop and manage water resources, and the delivery of water services (Rogers and Hall [17]). "Good governance" depends upon the principles of predictability, inclusivity, representivity, accountability, efficiency, effectiveness, social equity and justice. Other principles such as transparency are necessary to ensure safeguards in the system, while cooperation is necessary in a highly complex system. Causes of "ineffective governance" include corruption, inadequate financial resources, 
inadequate labour and managerial skills, low prioritization and poor communication (Moss et al. [18]).

According to Pegram et al. [19], "coherent governance of the water environment has been simplified by the definition of water resources under the NWA to include a "watercourse, surface water, estuary, or aquifer", ... while resource quality refers to the quantity, quality, habitat and biota of a water resource. These broad definitions together with the broad definition of water use to include abstraction, storage, streamflow reduction, waste discharge (including sea outfalls), waste disposal (with impact on water), in stream activities and recreation, provide a relatively integrated basis for water resources management.

South Africa's water resources policy and legislation is firmly grounded in the principles of the Constitution, considers international best practice around integrated water resources management (IWRM) (including decentralization and participation) within the historical context of South Africa requiring redress. The NWA develops a coherent and integrated governance framework around these concepts, addressing catchment level strategic planning, allocation, protection, development and utilization of the water resources and charging for water. It further provides for decentralized organizational framework for water resource management, based on the establishment of Catchment Management Agencies (CMAs).

However, the development and implementation of the necessary regulatory enabling framework for legislation and regulation has been slow, particularly in the delayed establishment of CMAs; transformation of WUAs; establishment of a water resources classification system; reallocation of water use entitlements, including compulsory licensing; development of catchment management strategies; authorisation of water use within a catchment paradigm; development of economic instruments under the charging strategy, such as the waste discharge charge system."

The Catchment Management Agencies (CMAs) are statutory bodies established in terms of chapter 7 of the NWA for the management for water resources. CMAs are responsible for the planning, implementation and management of water resources. Secondly, they are established to coordinate the water related activities of other organizations and water users. CMAs also play a role as organizations to which certain functions currently performed at national level may be delegated at regional or catchment level. The initial functions of the CMAs are mainly centered on managing the regional water resources and ensuring stakeholder participation within a Water Management Area (WMA).

WUAs are cooperative associations of water users established under the NWA to undertake water related activities for the mutual benefit of all its members within a WMA. Within the associations, members cooperate and pool resources to address local water related needs and priorities. WUAs are therefore mainly established to manage local water infrastructure, e.g. irrigation water supply schemes and to implement management decisions agreed upon between the members.

The Inkomati CMA establishment process began in 2000 and it was finally launched (the first in South Africa) during 2006. The Inkomati WMA is a 
combination of the Komati, Crocodile and Sabie-Sand Catchments. Within its jurisdiction falls the Crocodile Main Irrigation Board which still has to be transformed to a WUA. At present commercial agriculture, with crops such as sugar-cane, citrus and other sub-tropical fruit, is the main water user in the catchment.

Pegram et al. [19] further state that "delays in the development of key regulatory instruments have meant that the institutional and practical implementation of the policy and legal framework for water governance is not well developed. While this is not ideal, it has allowed improved understanding and implicit change within the sector and implies that the fundamental regulatory change may be introduced in a coherent manner over the next few years."

\section{Conclusion}

Considerable progress has been made with implementation of new approaches to water management according to the legal framework in South Africa. It is anticipated that acceptance of regulations to mandate water measurement will enable volumetric charging. This is an important economic instrument to relate financial water costs to water use and to provide incentives for efficient irrigation. At the same time a change from a unitary to a two-part charging system should be introduced. This will facilitate both demand management of water and balancing the budgets of CMA's and WUA's. Correct incentives for conservation and allocation of water will be instituted by a combination of accelerated compulsory licensing to achieve equity and promotion of water markets to achieve efficiency. Key requirements are restitution or redistribution of land together with water use rights and clear specification of the volume and reliability of available water attached to the use entitlement. Decentralisation of water management functions from DWAF central offices to CMA's finally requires cooperation and participation by all water users to ensure effective performance and governance.

\section{References}

[1] Department of Water Affairs and Forestry, National Water Resource Strategy (First Edition), Pretoria, 2004.

[2] Backeberg, G.R., Allocation of water use rights in irrigated agriculture: Experience with designing institutions and facilitating market processes in South Africa, USCID $4^{\text {th }}$ International Conference on Irrigation and Drainage, 3-5 October 2007, Sacramento, California, 2007.

[3] Gildenhuys, J.S.H., Public Financial Management, JL Van Schaik Publishers, Pretoria, 1997.

[4] Genesis Analytics, Part 1 The Contribution, Costs and Development Opportunities of Forestry, Timber, Pulp and Paper Industries in South Africa, Private Bag X1, Melrose Arch, Johannesburg, 2005

[5] Meiring, J.A., Oosthuizen, L.K., Botha, P.W. \& Crow, C.I., The implementation of the FARMS system for management decision-making in 
irrigation farming: Summary reports and user guides, WRC Report No 894/1-4/02, Pretoria, 2002.

[6] Oosthuizen, L.K., Botha, P.W., Grové, B., Meiring, J.A., Monkhei M.M. \& Pretorius, I.G., Cost Estimating Procedures for micro-, drip- and furrowirrigation systems for large- and small-scale farmers in the Onderberg/Nkomazi region, WRC Report No 974/1/05, Pretoria, 2005.

[7] Oosthuizen, L.K., Botha, P.W., Grové, B. \& Meiring, J.A., Cost-estimating procedures for drip-, micro, and furrow-irrigation systems, Water SA Vol 1 No 3 July 2005.

[8] Perret, S. \& Geyser, M. The full financial costs of irrigation services: A discussion on existing guidelines and implications for smallholder irrigation in South Africa, Water SA Vol 33 No 1, January 2007.

[9] Van der Stoep, I., Benadé, N., Smal, H.S. \& Reinders, F.B., Guidelines for irrigation water measurement in practice, WRC Report No TT 248/05, Pretoria, 2005.

[10] Department of Water Affairs and Forestry, Water Conservation and Water Demand management Conditions: Use of water for domestic, agriculture and industrial sectors, (Final report version 1.0), Directorate: Water Use Efficiency, Pretoria, 2006.

[11] Havenga, B., Personal Communication. 9 October 2006. DWAF. Pretoria.

[12] Lodewijks, H., Personal Comment, Anglo Coal, 2006.

[13] Gillitt, C.G., Water markets in irrigation areas of the lower Orange and Crocodile rivers of South Africa, Report No KV 160/04, Pretoria, 2005.

[14] Armitage, R.M., An economic analysis of surface irrigation water rights transfers in selected areas of South Africa, WRC Report No 870/1/99, Pretoria, 1999.

[15] Department of Water Affairs and Forestry, Guidelines for water allocation in South Africa: A framework for water allocation reform, (Draft 2.2), Directorate: Water Allocation, Pretoria, 2006.

[16] Nieuwoudt, W.L., Gillitt, C.G. \& Backeberg, G.R., Implication of risk in irrigation water transfers in South Africa, Proceedings of International Conference on Water Economics, Statistics and Finance, Ed. KP, 2005.

[17] Rogers, P. \& Hall, A., Effective water governance: Global Water Partnership, TEC Background Paper No 7, November 2002, in Pegram et al. 2006.

[18] Moss, J., et al. Valuing water for better governance CEO Panel: Business and Industry, 2003, in Pegram et al. 2006.

[19] Pegram, G., Mazibuko, G. Hollingworth, B. \& Anderson, E. Strategic review of current and emerging governance systems related to water in the environment in South Africa, WRC Report No 1514/1/06, Pretoria, 2006. 